\title{
ANALISIS KESALAHAN SISWA PADA OPERASI HITUNG PECAHAN BERDASARKAN TINGKAT KECERDASAN SISWA
}

\author{
Danty Rahmasantika, Rully Charitas Indra Prahmana \\ Universitas Ahmad Dahlan, Jl. Ringroad Selatan, Kragilan, Yogyakarta 55191
}

Email: rully.indra@mpmat.uad.ac.id

\begin{abstract}
Junior high school's students should be able to determine fraction and also implement the concepts of fraction to solve mathematics problem. However, in reality, so many mistake that occur for students in solving mathematics problem in the operation of fraction. The intelligence of students also affects the number of errors in solving the fractional counting operations. So, the purpose of this study was to determine students' errors in solving the problem of fractional counting operations based on the level of students' intelligence. This research is a descriptive qualitative research. The research results show that the different category of students' intelligent produce different mathematical problem solving abilities. Students with low intelligence categories make many errors in their completion. On the other hands, the student with high intelligence category make a few errors.
\end{abstract}

Keywords: Error Analysis, Fractions, Mathematical Problem Solving

\section{PENDAHULUAN}

Pendidikan matematika merupakan ilmu dasar dalam semua bidang kehidupan manusia yang memerlukan otak kita sebagai kemampuan berpikir. Sejalan dengan hal itu, melalui pembelajaran matematika seorang individu dapat membangun kemampuan berpikir kritis, dan logis, serta mengasah diri dalam memecahkan masalah (Badaruddin, Kadir, dan Anggo, 2016). Disisi lain, Amelia (2018) juga menyatakan bahwa matematika dapat mengembangkan pola pikir yang melibatkan pemikiran kritis, logis, sistematis, dan kreatif.

Ugi, Djadir dan Darwis (2016) menyatakan bahwa kesalahan dalam belajar merupakan suatu kondisi dimana seseorang mengalami hambatan-hambatan tertentu dalam proses belajar, yang berakibat pada hasil prestasi berada dibawah nilai standar yang telah ditentukan. Sejalan dengan hal itu, bentuk kesalahan yang lakukan oleh siswa berupa kesulitan dalam membangun dan memecahkan permasalahan matematika 
(Subanji \& Nusantara, 2013). Oleh sebab itu, kesalahan dalam belajar matematika merupakan suatu kondisi seseorang yang mengalami bentuk kesalahan berupa kesulitan/hambatan dalam membangun dan memecahkan permasalahan matematika, yang berakibat pada hasil prestasi berada dibawah nilai standar yang telah ditentukan.

Penyebab kesalahan yang biasa terjadi dalam mengerjakan soal matematika adalah disebabkan kurangnya pemahaman konsep materi prasyarat atau materi pokok yang telah dipelajari siswa, kurangnya penguasaan bahasa matematika, siswa keliru dalam menafsirkan dan/atau menerapkan rumus matematika, siswa tidak teliti dalam perhitungan matematika (Badaruddin, et al., 2016), sedangkan Subanji (2006) menyatakan bahwa kesalahan yang sering terjadi berupa proses berpikir pseudo penalaran; pseudo benar terjadi pada saat siswa memperoleh jawaban benar namun penalarannya salah, sedangkan pseudo salah terjadi saat siswa memperoleh jawaban salah namun penalarannya benar. Sehingga, kesalahan yang sering terjadi pada siswa ketika mengerjakan soal matematika adalah disebabkan karena kurangnya pemahaman konsep matematika yang dipelajari, kurangnya penguasaan bahasa matematika, siswa keliru dalam menerapkan rumus dan perhitungan matematika, serta terjadinya kemampuan proses berpikir pseudo penalaran benar dan salah.

Penelitian yang dilakukan oleh Edo (2015) menyatakan bahwa sebanyak 83\% mahasiswa mengalami kesulitan dalam menyamakan penyebut pecahan menggunakan KPK pada operasi penjumlahan dan pengurangan pecahan karena misconcepting dalam pengaplikasian soal matematika sudah yang diajarkan di Sekolah Dasar. Dalam kehidupan sehari-hari, konsep pecahan banyak sekali ditemui sebagai penyelesaian dalam berbagai permasalahan (Astuty \& Wijayanti, 2013: 1). Disisi lain, konsep pecahan dan operasinya juga penting untuk dipelajari sebagai materi prasyarat untuk materi selanjutnya (Prayitno \& Wulandari, 2015: 106). Jadi, pecahan merupakan materi yang dianggap sulit sebab terjadinya misconcepting bagi mayoritas orang, namun materi pecahan penting untuk dipelajari karena menjadi salah satu materi prasyarat untuk materi perbandingan tingkat Sekolah Menengah Pertama.

Edo dan Samo (2017) mengatakan bahwa guru kelas Sekolah Dasar kurang mendalami materi matematika karena didalam proses pembelajarannya mereka hanya terpacu pada buku pegangan matematika; Selain itu, guru SD terbiasa menerapkan metode ceramah mulai dari memberi penjelasan materi, memberi contoh soal, kemudian 
memberi latihan soal kepada siswa, hal tersebut mengakibatkan siswa terbiasa dengan latihan soal yang langkah penyelesaiannya mengikuti dengan contoh soal yang diberikan tanpa mengetahui konsep dari pecahan tersebut. Oleh sebab itu, guru SD atau tenaga pendidik berpengaruh besar terhadap pemahaman konsep siswa pada materi operasi hitung pecahan, dikarenakan dalam proses pembelajarannya guru SD hanya mengacu pada buku pengangan matematika sebagai media pembelajarannya dan metode ceramah yang dinilai kurang efektif dalam membangun pemahaman konsep siswa.

Penelitian yang telah dilakukan oleh Sahriah, Muksar, dan Lestari (2012) menghasilkan beberapa temuan kesalahan berupa kesalahan konseptual dan kesalahan prosedural pada siswa di SMP Negeri 2 Malang dalam menyelesaikan soal matematika operasi pecahan; Kesalahan konseptual yang dilakukan siswa yaitu: kesalahan tidak menyamakan penyebut, kesalahan konsep perkalian silang, kesalahan tidak memfaktorkan, dan kesalahan konsep pencoretan; sedangkan kesalahan prosedural yang dilakukan siswa yaitu: kesalahan tidak menuliskan variabel, kesalahan penjumlahan atau kesalahan perkalian atau kesalahan pembagian, kesalahan tidak menyederhanakan jawaban, kesalahan tidak menjawab soal, kesalahan menuliskan tanda, dan kesalahan memfaktorkan. Oleh sebab itu, beberapa kesalahan yang dilakukan siswa tersebut akan digunakan peneliti sebagai ide awal untuk menganalisis kesalahan siswa dalam menyelesaikan pada materi operasi pecahan pada penelitian ini.

Fatmawati, Mardiyana, dan Triyanto (2014) menyatakan bahwa secara generalisasi, kemampuan pemecahan masalah merupakan tujuan dari pembelajaran matematika dengan mengutamakan proses dan strategi dalam menyelesaikan permasalahan matematika. Sejalan dengan hal itu, penelitian ini menggunakan tahapan teori Polya yang ditemukan oleh George Polya karena langkah Polya menyediakan kerangka kerja yang tersusun rapi dalam menyelesaikan masalah matematika (Wati \& Sujadi, 2017). Langkah-langkah dalam analisis kesalahan dalam pemecahan masalah matematika menurut Polya ada 4, yaitu: memahami masalah, menentukan rencana strategi penyelesaian masalah, menyelesaikan strategi penyelesaian masalah, dan memeriksa kembali jawaban yang diperoleh (Komariah, 2011). Langkah tersebut merupakan langkah yang sangat tepat untuk digunakan dalam pemecahan masalah matematika berbentuk soal cerita.

Berdasarkan uraian di atas, peneliti tertarik untuk mengetahui kesalahan siswa 
dalam mengerjakan soal matematika pada materi operasi hitung pecahan. Harapannya penelitian ini dapat bermanfaat bagi tenaga pendidik dalam mengetahui letak kesalahan siswa dalam mengerjakan soal tersebut dan dapat mencari solusi permasalahannya.

\section{METODE PENELITIAN}

Penelitian ini dilakukan dengan 3 tahapan yaitu: tahapan persiapan (membuat instrument penelitian berdasarkan soal-soal yang sudah valid), tahapan pelaksanaan (memilih subjek penelitian, memberikan lembar tes kepada subjek penelitian), dan tahapan analisis (melakukan analisis data, memberikan kesimpulan). Tujuan penelitian ini yaitu untuk melihat bagaimana kemampuan pemecahan masalah dalam operasi hitung pecahan. Sesuai dengan tujuan tersebut, maka penelitian ini menggunakan pendekatan kualitatif deskriptif.

Penelitian ini dilakukan di SMP Negeri 1 Berbah Sleman Yogyakarta pada tahun pelajaran 2018/2019. Subjek penelitiannya adalah seluruh siswa kelas VIID dengan pemilihan subjek berdasarkan random sampling untuk mendapatkan hasil penelitian secara general pada sekolah tersebut. Instrument penelitian ini terdiri dari 10 soal yang diambil dari soal Ujian Nasional tahun-tahun sebelumnya, karena sudah pasti tingkat validitasnya. Sehingga instrument yang dibuat sudah layak untuk digunakan sebagai pengumpulan data penelitian.

Sumber data pengumpulan penelitian berupa hasil tes. Kemudian data hasil penelitian dianalisis dengan mengacu pada teori Polya, dengan mengutamakan proses dan strategi siswa dalam pemecahan masalah pada soal matematika materi operasi hitung pecahan. Sejalan dengan hal itu, analisis seluruh data dilakukan dengan 3 langkah utama, yaitu reduksi data, pemaparan data, dan penarikan kesimpulan.

\section{HASIL DAN PEMBAHASAN}

Data yang diperoleh dari hasil tes uraian siswa dibagi menjadi 2, yaitu: 5 soal menentukan nilai pecahan dan 5 soal menerapkan konsep-konsep pecahan kedalam perhitungan matematis dengan mengutamakan kemampuan penalaran matematis siswa. Penyajian data pada hasil penelitian ini dimulai dengan mengelompokkan soal yang berbeda perlakuan skor maksimalnya. Untuk soal 1-5 diberi skor maksimal sebanyak 5 skor, sedangkan soal 6-10 diberi skor maksimal sebanyak 10 skor. Hasil analisis data 
pemberian skor siswa berdasarkan analisis peneliti terhadap kesalahan di tiap langkah penyelesaian siswa dalam mengerjakan soal matematika materi operasi pecahan. Hasil analisis pemberian skor siswa berdasarkan kesalahan dalam mengerjakan soal matematika disajikan pada Tabel 1 .

Tabel 1. Hasil Analisis Skor Siswa Berdasarkan Tingkat Kesalahan Penyelesaian

\begin{tabular}{|c|c|c|c|c|c|c|c|c|c|c|c|c|}
\hline \multirow{2}{*}{ No } & \multirow{2}{*}{ Nama } & \multicolumn{5}{|c|}{ Butir Soal (Skor 1-5) } & \multicolumn{5}{|c|}{ Butir Soal (Skor 1-10) } & \multirow{2}{*}{$\begin{array}{c}\text { Jumlah } \\
\text { Skor }\end{array}$} \\
\hline & & 1 & 2 & 3 & 4 & 5 & 6 & 7 & 8 & 9 & 10 & \\
\hline 1 & Nabila & 4 & 3 & 1 & 2 & 5 & 5 & 2 & 0 & 0 & 0 & 22 \\
\hline 2 & Dika & 4 & 2 & 5 & 0 & 5 & 5 & 2 & 0 & 0 & 0 & 23 \\
\hline 3 & Helmy & 4 & 5 & 1 & 2 & 5 & 5 & 2 & 0 & 0 & 0 & 24 \\
\hline 4 & Karim & 3 & 2 & 4 & 0 & 5 & 8 & 3 & 0 & 0 & 0 & 25 \\
\hline 5 & Zainal & 4 & 1 & 4 & 5 & 5 & 3 & 2 & 2 & 0 & 0 & 26 \\
\hline 6 & Zahra & 4 & 4 & 3 & 2 & 5 & 7 & 2 & 0 & 0 & 0 & 27 \\
\hline 7 & Galang & 0 & 3 & 4 & 5 & 5 & 8 & 2 & 0 & 0 & 0 & 27 \\
\hline 8 & Ramdan & 4 & 5 & 5 & 2 & 5 & 5 & 2 & 0 & 0 & 0 & 28 \\
\hline 9 & Alfredta & 2 & 5 & 4 & 5 & 5 & 7 & 0 & 0 & 0 & 0 & 28 \\
\hline 10 & Reyhan & 2 & 5 & 2 & 0 & 5 & 5 & 3 & 3 & 2 & 3 & 30 \\
\hline 11 & Ananda & 3 & 0 & 0 & 5 & 5 & 5 & 3 & 3 & 3 & 3 & 30 \\
\hline 12 & Fiantika & 4 & 2 & 2 & 0 & 5 & 5 & 5 & 3 & 3 & 2 & 31 \\
\hline 13 & Galang & 4 & 5 & 5 & 5 & 5 & 5 & 2 & 0 & 0 & 0 & 31 \\
\hline 14 & Dwi & 5 & 2 & 5 & 5 & 5 & 10 & 3 & 0 & 0 & 0 & 35 \\
\hline 15 & Ayu & 5 & 2 & 4 & 5 & 5 & 8 & 6 & 0 & 0 & 0 & 35 \\
\hline 16 & Vania & 4 & 3 & 3 & 1 & 5 & 5 & 4 & 3 & 5 & 3 & 36 \\
\hline 17 & Dimas & 1 & 2 & 5 & 5 & 5 & 10 & 2 & 3 & 3 & 0 & 36 \\
\hline 18 & Ardian & 5 & 2 & 1 & 3 & 5 & 5 & 5 & 5 & 5 & 0 & 36 \\
\hline 19 & Natalia & 5 & 3 & 2 & 5 & 5 & 3 & 3 & 0 & 10 & 1 & 37 \\
\hline 20 & Maximina & 4 & 2 & 4 & 2 & 5 & 7 & 5 & 3 & 3 & 2 & 37 \\
\hline 21 & Hangga & 5 & 1 & 4 & 3 & 5 & 5 & 5 & 5 & 5 & 0 & 38 \\
\hline 22 & Naurah & 4 & 2 & 2 & 5 & 5 & 5 & 10 & 3 & 3 & 0 & 39 \\
\hline 23 & Riskalina & 4 & 5 & 5 & 5 & 5 & 7 & 9 & 3 & 3 & 1 & 47 \\
\hline 24 & Dhamar & 4 & 5 & 5 & 0 & 5 & 10 & 3 & 5 & 10 & 0 & 47 \\
\hline 25 & Rahmalia & 5 & 5 & 1 & 5 & 5 & 7 & 10 & 3 & 3 & 3 & 47 \\
\hline 26 & Johana & 5 & 4 & 4 & 5 & 5 & 7 & 7 & 3 & 5 & 3 & 48 \\
\hline 27 & Hanan & 4 & 5 & 5 & 5 & 5 & 5 & 10 & 3 & 10 & 0 & 52 \\
\hline 28 & Fernando & 5 & 5 & 3 & 5 & 5 & 10 & 10 & 10 & 0 & 0 & 53 \\
\hline 29 & Annida & 5 & 2 & 4 & 5 & 5 & 7 & 3 & 10 & 10 & 3 & 54 \\
\hline 30 & Najmu & 5 & 2 & 5 & 4 & 5 & 10 & 3 & 10 & 10 & 3 & 57 \\
\hline \multicolumn{2}{|c|}{ Jumlah } & 117 & 94 & 102 & 101 & 150 & 194 & 128 & 80 & 93 & 27 & \\
\hline \multicolumn{2}{|c|}{ Skor min: } & \multicolumn{10}{|c|}{22} & \\
\hline \multicolumn{2}{|c|}{ Skor maks: } & \multicolumn{10}{|c|}{58} & \\
\hline \multicolumn{2}{|c|}{ Rata-rata: } & \multicolumn{10}{|c|}{36.20} & \\
\hline
\end{tabular}




\section{Rahmasantika \& Prahmana, Analisis Kesalahan Siswa pada Operasi Hitung Pecahan Berdasarkan Tingkat Kecerdasan Siswa}

Berdasarkan Tabel 1, dari keseluruhan siswa diperoleh skor minimal sebesar 22, skor maksimal sebesar 58, dan rata-ratanya sebesar 36.20. Pada siswa yang memperoleh nilai minimal, dikarenakan siswa tersebut kurang dalam kemampuan perhitungan dan pemecahan masalah matematisnya. Sedangkan pada siswa yang memperoleh nilai maksimal, dikarenakan siswa tersebut sudah menerapkan konsep-konsep pecahan dan melakukan perhitungan matematis dengan baik.

Dari hasil skor tersebut, dikategorikan menjadi 3 tingkat kecerdasan siswa berdasarkan rentang skor tertentu, yaitu tingkat kecerdasan rendah, tingkat kecerdasan sedang, dan tingkat kecerdasan tinggi. Rekapitulasi tingkat kecerdasan siswa disajikan pada Tabel 2.

Tabel 2. Rekapitulasi Tingkat Kecerdasan Siswa

\begin{tabular}{cccc}
\hline No & Rentang Skor & Jumlah Siswa & Keterangan \\
\hline 1 & $0-25$ & 4 & Tingkat Kecerdasan Rendah \\
2 & $26-50$ & 22 & Tingkat Kecerdasan Sedang \\
3 & $51-75$ & 4 & Tingkat Kecerdasan Tinggi \\
\hline
\end{tabular}

Berdasarkan Tabel 2, dengan subjek penelitian sebanyak 30 siswa, kita dapat mengetahui bahwa pada rentang skor 0-25 terdapat 4 siswa dikategorikan tingkat kecerdasan rendah, pada rentang skor 26-50 terdapat 22 siswa dikategorikan tingkat kecerdasan sedang, dan pada rentang skor 51-75 terdapat 4 siswa dikategorikan tingkat kecerdasan tinggi. Hasil keberagaman skor siswa menunjukkan bahwa instrument tes yang disajikan sudah cukup baik dan dapat digunakan untuk mengukur tingkat kecerdasan siswa berdasarkan tingkat kesalahan penyelesaiannya.

Berdasarkan tingkat kecerdasan siswa yang sudah kita ketahui, selanjutnya akan diambil 1 sampel siswa dari tingkat kecerdasan rendah, 1 sampel siswa dari kecerdasan sedang, dan 1 sampel siswa dari kecerdasan tinggi. Kemudian dapat kita lihat penyelesaian matematika dari masing-masing sampel tersebut berdasarkan teori Polya.

Diambil seorang sampel dari tingkat kecerdasan rendah dengan perolehan skor 22. Selanjutnya, dianalisis 2 buah penyelesaian permasalahan matematikanya. No.3 dan No.8 yang dipilih peneliti, dikarenakan keduanya memiliki skor dengan perolehan terendah, seperti tampak pada Gambar 1 dan Gambar 2. 


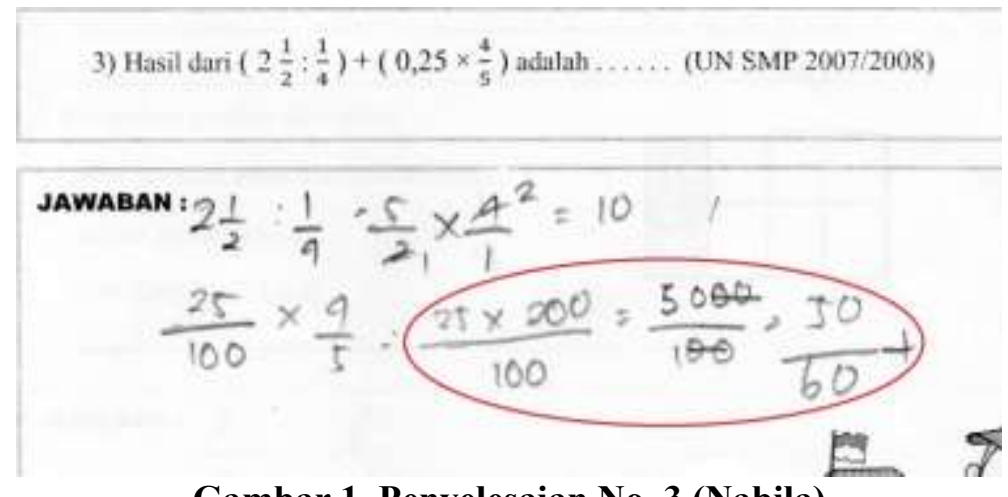

Gambar 1. Penyelesaian No. 3 (Nabila)

Berdasarkan Gambar 1, Nabila hanya mampu memahami rencana dari permasalahan tersebut, dikarenakan Nabila hanya mampu menulis kembali permasalahan dengan benar. Namun, Nabila tidak mampu mengoperasikan permasalahan matematika tersebut dengan benar, sehingga Nabila belum mampu menentukan nilai pecahan yang ditanyakan oleh soal.

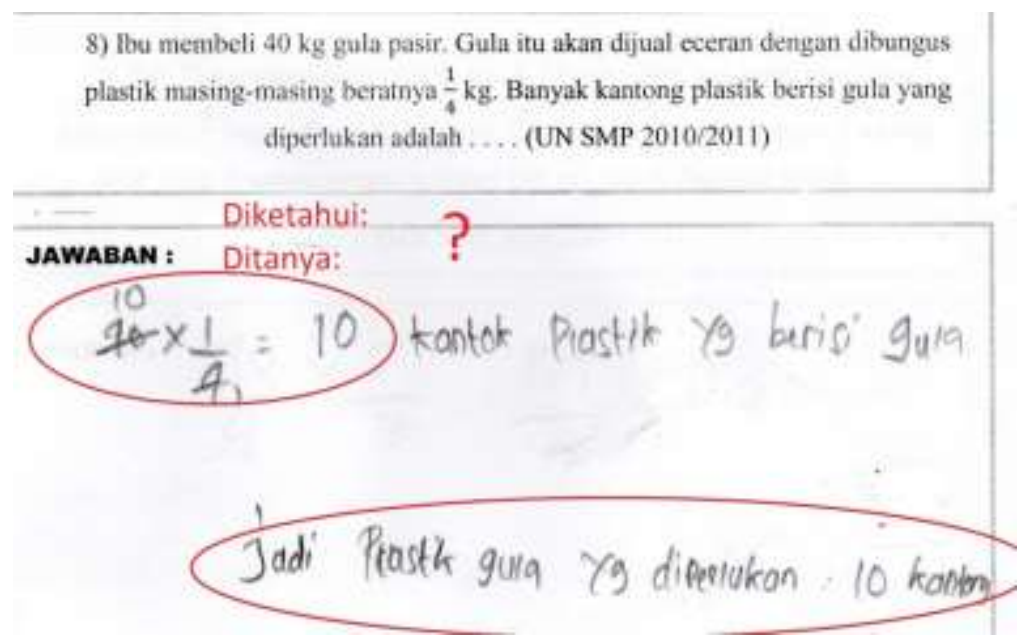

Gambar 2. Penyelesaian No. 8 (Nabila)

Gambar 2 menjelaskan bahwa Nabila belum mampu memahami rencana, dikarenakan tidak menulis apa yang diketahui dan ditanyakan dari permasalahan matematika tersebut. Disisi lain, Komariah (2011: 184) menyatakan bahwa pada tahapan pertama dari langkah Polya adalah siswa mampu menganalisis masalah, dengan menunjukkan apa yang diketahui, apa yang ditanya, dan apa yang diperlukan. Kemudian pada tahapan merencanakan pemecahan, pelaksanaan rencana pemecahan, dan melihat kembali hasil belum dapat dilakukan Nabila dengan baik. Sehingga teori Polya pada No. 8 belum dapat Nabila lakukan. Sejalan dengan hal itu, Nabila dapat dikatakan belum mampu menerapkan konsep-konsep pecahan

Selanjutnya, Maximina dipilih sebagai sampel dari kategori kecerdasan sedang 
dengan perolehan skor 37 dari skor maksimalnya adalah 75. Soal No.1 dipilih peneliti untuk menganalisis kemampuan siswa dalam menentukan nilai pecahan, dan soal No.6 dipilih peneliti untuk menganalisis kemampuan siswa dalam menerapkan konsep-konsep pecahan, seperti tampak pada Gambar 3 dan Gambar 4.

$$
\text { 1) Hasil dari } \frac{\frac{5}{6}+\frac{1}{3}}{6}-\frac{1}{3} \text { adalah. ....... (UN SMP 2017/2018) }
$$

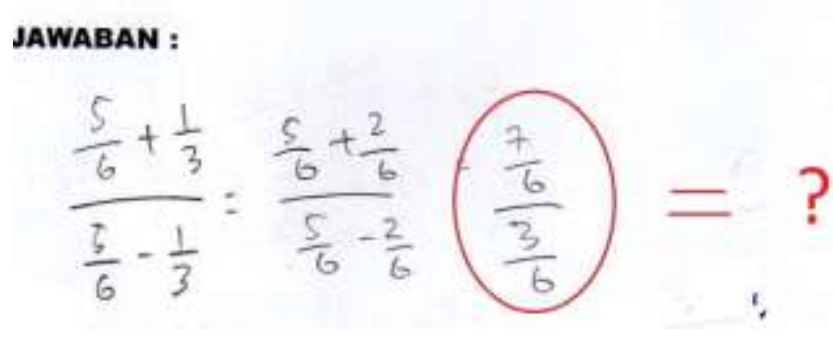

Gambar 3. Penyelesaian No.1 (Maximina)

Maximina sudah dapat memahami rencana dan merencanakan pemecahan dengan baik. Namun, Maximina belum dapat menentukan nilai pecahan, dikarenakan perhitungan matematisnya belum tuntas (Gambar 3)

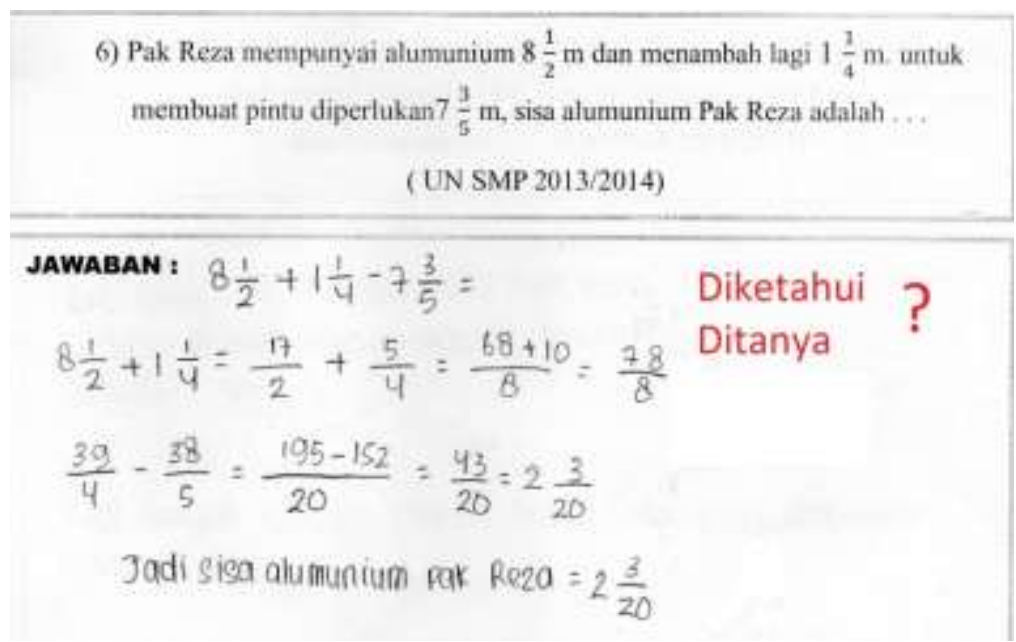

\section{Gambar 4. Penyelesaian No. 6 (Maximina)}

Maximina belum mampu memahami rencana, dikarenakan tidak menuliskan apa yang diketahui dan ditanyakan pada permasalahan matematika tersebut.. Sedangkan, pada tahapan merencanakan pemecahan, pelaksanaan pemecahan, dan melihat kembali hasil dapat dilakukan Maximina dengan baik. Sejalan dengan hal itu, Maximina dapat dikatakan sudah mampu menerapkan konsep-konsep pecahan walaupun teori Polya pada 
No. 6 belum Maximina laksanakan sepenuhnya seperti yang disajikan pada Gambar 4 .

Dari kategori tingkat kecerdasan tinggi, peneliti memilih Najmu sebagai sampel dengan perolehan skor tertinggi yaitu 57. Soal No.3 dan soal No.9 dijadikan sampel oleh peneliti untuk dianalisis kemampuan pemecahan masalahnya. 2 soal tersebut cukup mewakili kategori tingkat kecerdasan tinggi dari seorang siswa, seperti tampak pada Gambar 5 dan Gambar 6.

3) Hasil dari $\left(2 \frac{1}{2}: \frac{1}{4}\right)+\left(0,25 \times \frac{4}{5}\right)$ adalah $\ldots . .$. (UN SMP 2007/2008)

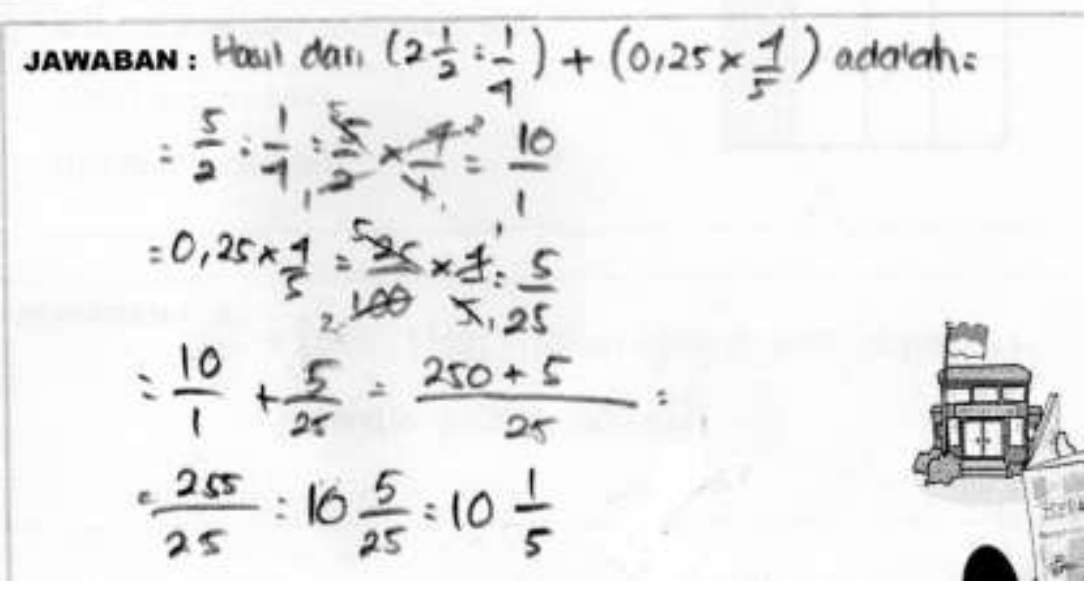

Gambar 5. Penyelesaian No. 3 (Najmu)

Penyelesaian Najmu seperti tampak pada Gambar 5, menunjukkan bahwa Najmu dapat menjawab dengan benar, langkah pengerjaannya terurut. Sehingga Najmu sudah dapat menentukan nilai pecahan dengan baik sesuai dengan konsep-konsep pecahan. 
9) Ina membagikan $12 \mathrm{~kg}$ kopi kepada beberapa orang. Jika setiap orang mendapat $\frac{1}{4} \mathrm{~kg}$ kopi, maka banyak orang yang menerima kopi adalah

(UN SMP 2009/2010)

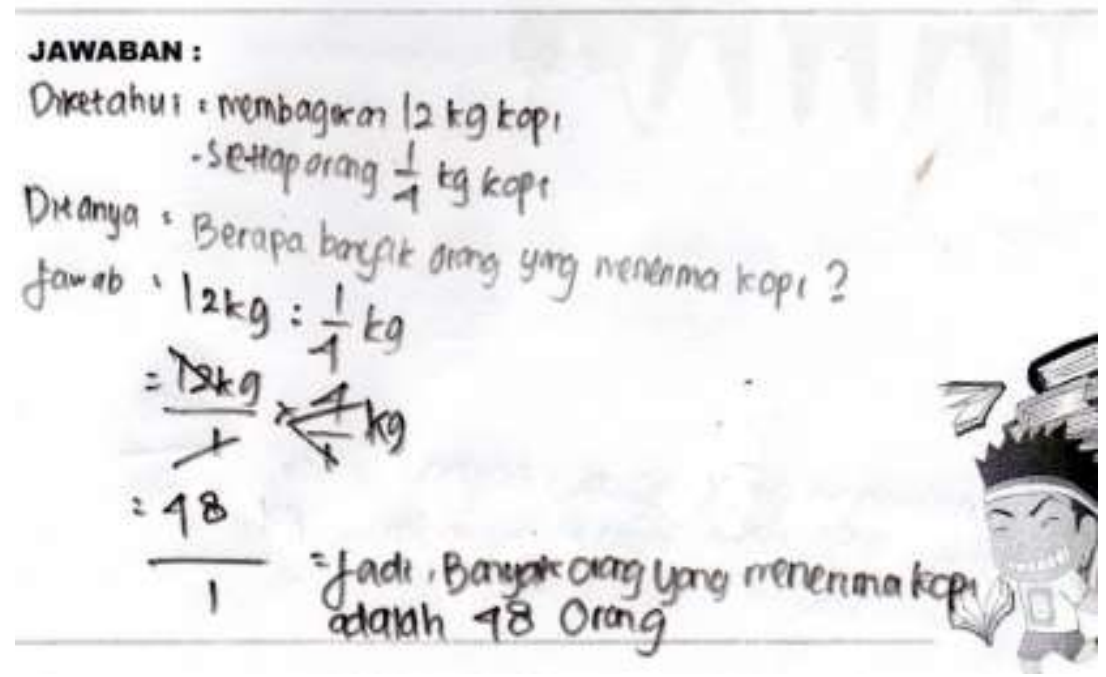

Gambar 6. Penyelesaian Soal No.9 (Najmu)

Terdapat tulisan apa yang diketahui, apa yang ditanya, dan apa yang diperlukan sehingga dapat kita ketahui bahwa Najmu mampu memahami rencana dengan baik. Tahapan merencanakan pemecahan, pelaksanaan perencanaan pemecahan, dan melihat kembali hasil dapat dilakukan Najmu dengan sangat baik (Gambar 6). Dengan begitu Najmu sudah menerapkan konsep-konsep pecahan, dan sudah melakukan tahap penyelesaian permasalahan Teori Polya dengan sepenuhnya. Sesuai dengan pernyataan Nurmalasari (2014: 5) yang menyatakan bahwa siswa yang tingkat kemampuan matematiknya tinggi mampu menganalisis dan mentransformasikan permasalahan matematika kedalam model matematika

Berdasarkan hasil dan pembahasan tersebut, dapat diketahui bahwa kategori kecerdasan siswa yang berbeda, menghasilkan kemampuan pemecahan masalah matematis yang berbeda pula. Siswa dengan kategori kecerdasan rendah, menghasilkan banyak kesalahan dalam penyelesaiannya. Begitu juga kebalikannya, penyelesaian matematika pada siswa kategori kecerdasan tinggi, menghasilkan kesalahan yang sedikit 
Rahmasantika \& Prahmana, Analisis Kesalahan Siswa pada Operasi Hitung Pecahan Berdasarkan Tingkat Kecerdasan Siswa

\section{SIMPULAN}

Siswa dengan kategori kecerdasan rendah belum dapat menentukan nilai pecahan dengan benar, belum mampu menerapkan konsep-konsep pecahan dalam bentuk soal cerita, dan langkah-langkah penyelesaiannya belum sesuai dengan Teori Polya. Selanjutnya, siswa dengan kategori kecerdasan sedang belum mampu menentukan nilai pecahan dengan tuntas, dapat menerapkan konsep-konsep pecahan dalam bentuk soal cerita, dan langkah-langkah penyelesaiannya belum sesuai dengan Teori Polya. Terakhir, siswa dengan kategori kecerdasan tinggi sudah mampu menentukan nilai pecahan dengan benar, mampu menerapkan konsep-konsep pecahan dalam bentuk soal cerita, dan langkah-langkah penyelesaiannya sudah sesuai dengan Teori Polya.

\section{DAFTAR RUJUKAN}

Amelia, R. (2015). Pencapaian penerapan kemampuan penalaran matematis siswa SMP dengan menggunakan inkuiri terbimbing. Jurnal Ilmiah UPT P2M STKIP Siliwangi, 2(1), 98-115.

Astuty, K.Y., \& Wijayanti, P. (2013). Analisis Kesalahan Siswa Kelas V dalam menyelesaikan materi pecahan. Jurnal MATHEdunesa, 2(3), 1-7.

Badaruddin, Kadir, \& Anggo, M. (2016). Analisis Kesalahan Dalam Menyelesaikan SoalSoal Operasi Hitung Pecahan Pada Siswa Kelas VII SMP Negeri 10 Kendari. Jurnal Penelitian Pendidikan Matematika, 4(2), 43-56.

Edo, S.I. (2016). Jenis Kekeliruan Akibat Menghafal Prosedur Rutin Dalam Melakukan Operasi Penjumlahan Dan Pengurangan Bilangan Pecahan. Jurnal Mosharafa, 5(3), 223-234.

Edo, S.I., \& Samo, D.D. (2017). Lintasan Pembelajaran Pecahan Menggunakan Matematika Realistik Konteks Permainan Tradisional Siki Doka. Jurnal Mosharafa, 6(3), 311-322.

Fatmawati, H., Mardiyana, \& Triyanto. (2014). Analisis Berpikir Kritis Siswa Dalam Pemecahan Masalah Matematika Berdasarkan Polya Pada Pokok Bahasan Persamaan Kuadrat. Jurnal Elektronik Pembelajaran Matematika, 2(9), 899-910.

Komariah, K. (2011: 184). Penerapan Metode Pembelajaran Problem Solving Model Polya Untuk Meningkatkan Kemampuan Memecahkan Masalah Bagi Siswa Keas IX J DI SMPN 3 CIMAHI. Prosiding Seminar Nasional Penelitian, Pendidikan dan Penerapan MIPA, Fakultas MIPA, Universitas Negeri Yogyakarta, 181-218.

Nurmalasari, W. (2016). Analisis Pemecahan Masalah dalam Penyelesaian Soal Pecahan Kelas Vii Smp Muhammadiyah 1 Surakarta Tahun 2015/2016. eprints.ums.ac.id/44807/

Prayitno, A., \& Wulandari, D.T. (2015). Meminimalkan Kesalahan Konsep Pecahan Melalui Pembelajaran Penemuan Terbimbing Dengan Gesture Produktif Pada Siswa SMP. Jurnal Pendidikan Matematika, 1(2), 106-117. 
Sahriah, S., Muksar, M., \& Lestari, T.E. (2012). Analisis Kesalahan Siswa Dalam Menyelesaikan Soal Matematika Materi Operasi Pecahan Bentuk Aljabar Kelas VIII SMP Negeri 2 Malang. Jurnal: Universitas Negeri Malang, 1(1), 1-10.

Subanji, \& Nusantara, T. (2013). Karakterisasi Kesalahan Berpikir Siswa dalam Mengonstruksi Konsep Matematika. Jurnal Ilmu Pendidikan, 19(2), 208-217.

Subanji. (2006). Berpikir Pseudo Penalaran Kovariasi Dalam Mengkontruksi Grafik Fungsi Kejadian Dinamik: Sebuah Analisis Berdasarkan Kerangka Kerja VL2P Dan Implikasinya Pada Pembelajaran Matematika. Jurnal Ilmu Pendidikan, 13(1), 1-8.

Ugi, L.E., Djadir, \& Darwis, M. (2016). Analisis Kesalahan Siswa Pada Operasi Hitung Campuran Bilangan Bulat Dan Alternatif Pemecahannya. Jurnal Daya Matematis, 4(1), 34-50.

Wati, M.K, \& Sujadi, A.A. (2017). Analisis Kesalahan Dalam Menyelesaikan Masalah Matematika Dengan Menggunakan Langkah Polya Siswa Kelas VII SMP. Jurnal PRISMA Universitas Suryakancana, 6(1), 9-16. 